\title{
Sustainable Architecture Concept in Islam
}

\author{
$1^{\text {st }}$ Putri Suryandari ${ }^{1}$ \\ putrisyd@gmail.com \\ putri.suryandari@budiluhur.ac.id ${ }^{1}$ \\ UIN Syarif Hidayatullah, Islamic Architecture Studies, Jakarta, Indonesia ${ }^{1}$ \\ University of Budi Luhur, Architecture, Jakarta, Indonesia ${ }^{1}$
}

\begin{abstract}
Global warming is currently a very troubling world problem, one of which is triggered by the greenhouse effect of the development of modern architecture, in the form of tall buildings. Sustainable development emerged in response to the dramatic growth in understanding that modern development practices lead to environmental and social crises throughout the world. Islam is a religion that gives mercy to the universe, has warned that humans will do damage on earth on the pretext of improving the environment. If Islam (Al Quran) has given a warning about the possibility of damage on earth due to the development of the human mind set in dealing with the environment, of course Islam also leaves an answer to solve the problem. This research will explore what guidelines in the philosophy of Islamic (architecture) are environmentally friendly and sustainable, so as to save the inhabitants of the earth from destruction because of the effects of modern development. The research method is qualitative by conducting a literature and case study. A case study conducted at the Beleq traditional settlement in Gumantar, Lombok, which survived handreds of time int the earthquake 2018, as an example of sustainable architectural planning, according to Islamic principles.
\end{abstract}

Keywords: Global warming, sustainable development, Islamic (architecture) environmentally friendly and sustainable

\section{Global Warming and Decrease Of Environmental Quality in The World}

Over the last 10 years the world was shocked by the emergence of a film that raised the issue of global warming. The world, which is currently divided into four major climatic groups, is suddenly faced with the same heat and uniform conditions throughout the world. This is the condition known as Global Warming. [1]

The last hundred years, architectural planning in the world uses the concept of Modern Architecture. The building is shaped vertically or horizontally by referring to the International style. The emergence of this International Style is partly due to the industry review (18001900), where the material industry produces mass products. This mass production forces producers to market their products throughout the world, so that globally form the same building style. Building components and materials are mass-produced and used throughout the world, without considering climate characteristics, geographical factors and local culture. economic factors and efficiency are the main considerations. [2]

To obtain visual and thermal comfort (environmental control), the use of AC (Air Conditioning) and energy-intensive lighting in buildings, is the solution. 
The current architectural work relies on enormous energy consumption, both at the time of instruction, and after operation.

The architecture of this period turned out to have a sizeable contribution to environmental damage that is $60 \%$, while housing meets $40 \%$ of that amount. Housing has a significant amount in contributing to environmental problems, because the number of people is increasing every year and continues to require building a comfortable and durable home . [2]

In connection with rising global temperatures, the contribution of architecture is very large in raising the micro climate, especially urban areas. The increase in the microclimate is caused by heat emitted by buildings and roads. The role given by buildings and building equipment, among others, is the use of heat energy and lighting for the convenience of its users. Besides the reflection of the sun's heat on building materials in the form of glass walls on tall buildings, as well as road pavement materials, contributes greatly to global warming. [3]

The point of Modern Architecture with international style, has been destroying nature for less than 100 years. Development that is concerned with human comfort rather than the environment has caused worldwide damage, so to solve the problem comes a derivative of Sustainable Development namely, Sustainable Architecture, Green Architecture, Eco Architecture and Environmentally Sensitive Design (ESD). But whether the concept is able to solve global environmental problems in building spatial planning, as well as building group spatial planning in the current era of modern architecture?

As a comparison, the concept of modern and traditional settlement space in Indonesia, shows that natural disasters such as earthquakes, volcanic eruptions, floods, landslides, droughts, or forest fires have occurred regularly in Indonesian territory. The culture of traditional housing development has been able to help preserve natural resources, the environment and ecosystems in Indonesia, for hundreds of years. Geographical conditions give birth to forms of housing that are appropriate to the culture and characteristics of the area. History also proves that traditional buildings are sensitive and safe from natural disasters. [1]

Earthquakes are a natural disaster problem that is common in islands such as Indonesia. This disaster has been repeatedly experienced by our ancestors from time to time, so that the construction of houses has been adapted to the potential and the existing natural problems. Traditional buildings are made to reduce the risk of death in humans caused by the risk of natural disasters. Traditional buildings by utilizing local wisdom have been proven to protect people from the effects of natural disasters. The type, shape, structure, ventilation and disposal of waste in the process of forming traditional buildings, depends on many factors including culture, area, religion, topography, and geographical conditions.[4]

Described in ash-Shahiihain from Abu Hurairah Radhiyallahu anhu, that the Prophet sallallaahu 'alayhi wa sallam said to Gabriel Alaihissallam when he asked about the time of Resurrection:

"But I will mention to you the signs ... (then he mentioned, among them :) if the goat herders are competing to raise the building, then that is among the signs."

While in Muslim history it is revealed:

"And you witness people who do not wear sandals, naked and poor who are sheep herding, competing to make tall buildings." [5]

Seeing the development of architectural practices as written above, it is truly true that humans are makers of damage on earth. The practice of developing building planning technology under the pretext of human comfort turned out to have damaged the earth in a short time. 
It says in the Qur'an (QS.Al baqarah: 11-12); "And when it is said to them:' Do not cause mischief on earth '. They answered: 'Truly we are the ones who made improvements'. Remember, in fact they are the people who make damage, but they are not aware. ,

If in the Islamic religious guidelines ( $\mathrm{Al}$ Quran) it has been explained about the possibility of damage on earth, due to the development of the human mind set in dealing with the environment, of course Islam also leaves an answer to solve the problem.

This research seeks to examine how the basic guidelines of Islam (Al Quran and Hadist), in space planning and architecture that is sustainable and does not leave the effects of environmental damage on earth.

This research also wants to find out whether the traditional spatial concept is in accordance with Islamic architecture, so that it can be sustained until now.

\subsection{Problems}

In Islam, science is part of the teachings in the holy books ( $\mathrm{Al}$ Qur'an and Hadith), the holy book must be dissected in order to produce a guide to the guidelines for architectural planning that is sustainable and "safe" until the end of time.

The question is, what exactly is the philosophy in Islam regarding the planning of sustainable and environmentally friendly architectural spatial planning? Islam?

How is the compatibility of the traditional spatial concept with sustainable architecture in

\subsection{Purpose}

This research will explore what guidelines in the philosophy of Islamic (architecture) are environmentally friendly and sustainable, so as to save the inhabitants of the earth from destruction because of the effects of modern development, from Al Qur'an and Hadith.

As a case study is a traditional spatial and building concept that currently survives and continues to be sustainable, in building structures and spatial planning from natural disasters and changing times

\subsection{Research Method}

The research method is qualitative by conducting a literature and case study.

Primary data sources in this study are the results of the study of the concept of sustainable architecture and Islamic architecture obtained through literature, journals, and related articles, the Qur'an and Hadith.

The discussion in traditional buildings has compared it to the application of its design concepts with sustainable Islamic architecture.

\section{Theoritical Review}

\subsection{Islamic Architecture}

Architecture is a place for human activities in the form of buildings that have aesthetic and cultural values. Architecture can also be in the form of a building area that consists of 
various activity facilities that accommodate a lot of human activities. Islam as a religion rahmatan lil alamin places Islamic values in every aspect of life, non-destructive, full of grace, and the love of life. Allah created humans as caliphs on this earth means that humans are leaders, as well as maintainers and keepers. [7]Understanding Islam literally means peace, safety, submission, and cleanliness. The word Islam is formed from three letters, namely $\mathrm{S}$ (sin), L (lam), M (mim) which means the basis of "salvation" (Salama). So if we interpret Islamic Architecture, it means that architecture is saved. It is important for us human beings to obtain a philosophy of space planning and architecture that is safe for humans and the entire universe, sustainable until the end of time.

To understand about Islamic Architecture there are two approaches, the first approach is object-oriented as a product of Islamic society, while the second approach looks more at basic values and principles in Islam. This second approach is developed in this research.

Application of Islamic principles in architecture is expected to be able to guarantee the relationship of

1. Practicing revelation (Firman) Allah,

2. Processing the revelation with logic

3. shape / form

This arrangement results in the concept of Islamic architecture which rests on the Qur'an and Hadith. [8]

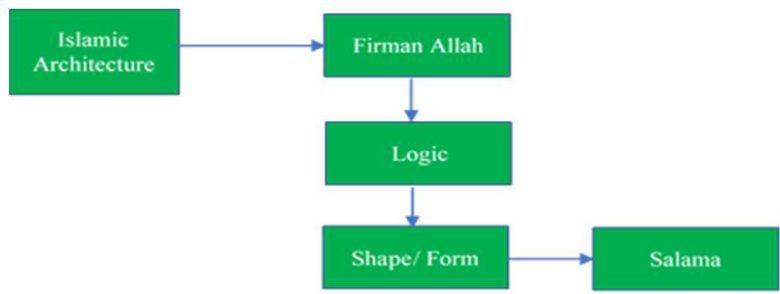

Figure 3. Islamic Architecture

\subsection{The Concept Of Sustainable Architecture In The Modern Century}

In 1987, the World Commission on Environment and Development (WCED), also called the Brundtland Commission, discussed a central theme, Our Common Future, also known as the Brundtland Report. This report illustrates the possibility of a new era of economic growth, something that must be based on policies that maintain and expand existing environmental resources.

So then in this Brundtland report formulated sustainable development or sustainable development, the understanding is as:

"Development that meets the needs of the present without reducing the ability of future generations to meet their own needs". Green architecture defines an understanding of environment-friendly architecture under all classifications, and contains some universal consent. [6]

It may have many of these characteristics:

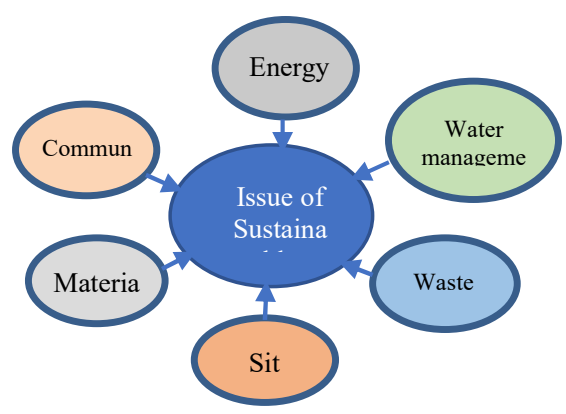


Figure 2. Issues for Sustainable Architecture

\subsection{Energy saving}

- Make use of sunlight

- Make use of natural air

- Make use of rain water

- The concept of efficient use of energy such as lighting

$\checkmark$ Turn off lights and electronic devices such as TVs or air conditioners when not needed.

$\checkmark$ Set the air conditioner to room temperature at 24 degrees.

$\checkmark$ Use energy saving lamps or LEDs.

\subsection{Water efficiency}

To anticipate the clean water crisis, we must develop a system of reducing water usage (reducing), reusing water for various purposes at once (reuse), recycling clean water (recycle), and refilling ground water (recharge)

\subsection{Reducing CO2 emissions / Waste}

- Create an organic waste decomposition system

- Create a domestic sewage treatment system

- $\quad$ Reuse, reduce and recycling

\subsection{Efficiency of material resources / Site}

- Use land efficiently

- Green potential of plants in the land

- Appreciate the presence of plants in the land

- Open design with spaces that open to the garden

- In design planning, consider various things

\subsection{Community}

Development that meets the needs of the present without compromising the ability of future generations to meet their own needs. These needs differ depending on location and community.

\section{The Concept of Sustainablilty in Islam}

The beginning of the creation of this earth according to Islam was intended for humans (Muhammad), but it did not start from the appearance of humans, but through the creation of 
the universe that was formed through 6 periods ("An-Nazi'at Letter: 27-33) namely: 1 sky, 2. the universe, 3. the sun and the solar system, 4 earth, 5. water, animals and plants, 6. human

"Are you more difficult to create or is the sky that Allah has built, (QS.79.27). He elevated the building and then perfected it, (QS.79.28). and He makes the night pitch black, and makes the day bright, (QS.79.29). And the earth after that He spread, (QS.79.30). He radiates from there his springs, and grows his plants, (QS.79.31). And the mountains he planted firmly, (QS.79.32). All that for your pleasure and for your livestock animals (QS.79.33) ".

The principles of sustainable architecture in the Qur'an are as follows:

\section{a. Energy Savings}

The concept of making the night completely dark and the day being brightly lit, is one of the warnings for the continuation of energy utilization, (letter An Naziaat 30: "... and He makes the night pitch black and makes the day bright,“"

At present the conditions that occur are, the night becomes as if the afternoon with the emergence of artificial lighting. Day into night, with the construction of large buildings without openings that are able to enter sunlight in the building, so it must add considerable artificial lighting. This behave is considered excessive and is a prohibition in the Qur'an.

The Qur'an states that the sun and moon (day and night) are in their circulation, so the balance of day and night must be maintained to maintain the balance of the universe, ( $\mathrm{Al}$ Anbiyaa: 33$)$.

\section{b. Water efficiency and management system}

The management of clean water is sourced from the cycle of springs that emanate from the Earth and grow vegetation (An Naziaat 31), then water comes down from the sky that runs through rivers and grows green plants (Al An'Am 99). Management of clean water sources that have a cycle of rotation from earth to sky and spinning again, is a cycle that must be passed to manage clean water. Storage of water bags in the river and at the roots of plants must always be maintained.

According to the hadith of the Prophet Muhammad SAW through ablution activities, water is saved by counting the number of washings on the affected limbs. So that running water in the ablution place can be done using a measured system. Measurable methods can create efficiency in water management system.

\section{c. Reducing $\mathrm{CO} 2$ emissions / Waste}

Islam calls for efficient use of natural resources and minimization of waste. God says in the Quraysh of Al-Araf 7:31: "Eat and drink, but don't waste it; "He" doesn't love excessively ".

Excessive eating and drinking produce garbage and garbage has now become a global problem. Indeed, people who believe in Al Qur'an can start reducing waste by eating and drinking in moderation.

The Center for Earth, Disaster, and Climate Change Studies at the Surabaya Institute of Technology (ITS) explains that food waste consumes a large potential of natural resources, but instead contributes to negative environmental impacts.

After being in a landfill, damaged food will produce methane gas, Methane 23 times stronger than $\mathrm{C} 02$ to contribute to the formation of greenhouse gas emissions. 
Combustion of garbage directly contributes $\mathrm{CO} 2$ gas which causes air pollution and shortness of breath.

The call to maintain cleanliness is one way not to dispose of waste and always protect the natural environment. It is stated in Surah Al Baqarah: 222, ".... Truly Allah loves those who repent and those who purify themselves and cleanse themselves".

\section{d. Efficiency of Material Source / Site}

In the environment where humans are, it cannot be denied that the presence, animals, plants, air, wind, rain, water and fire, are inseparable parts of humans. That part of the environment that has been formed around humans is a complement that cannot be left behind.

The Prophet -Shallahu Alaihi Wasallam-, he said,

"There is no Muslim who plants trees or plants, then birds eat it or humans or animals, except he will get alms because of it". [HR. Al-Bukhoriy in the Book AL-Muzaro'ah (2320), and Muslims in the Book of Al-Musaqoh (3950)]

For humans who guard the earth in accordance with the instructions of the Al Qor'an and Hadith, the sustainability of the earth will be maintained and likened to its continuity as life in heaven,

"The parable of heaven promised to the righteous (is like a garden) flows underneath rivers; always bear fruit and shade. That is the place of end for the righteous; while the end for those who deny God is hell '(Surah Ar Ra'd: 35)

Heaven is described as a very comfortable place for humans in the future, if humans are able to preserve nature, while disasters such as in hell are if humans apply otherwise, meaning that the principle of sustainable development must pay attention to these components as outputs in planning.

In the Buchary Muslim Hadith, the home of the Prophet Muhammad is a rectangular building on a stretch of desert that is arid. This building is only made of clay, floored and roofed with a very simple palm frond. The size of the Prophet's house is only $5 \times 3$ square meters and the roof is $2.5 \mathrm{~m}$ high,

For a great prophet like him, having a large and spacious house is possible, but he gives a different example. This condition illustrates that the prophet taught Muslims not to boast grandly with a dwelling, just to use the materials around the dwellings and minimal land.

The current reality, the concept of land and material efficiency is the basis for sustainable architecture.

\section{e. Community}

In the creation of the heavens and the earth, Allah created tribal and national people (Sura Al Hujarat: 13). So It is said that we all know each other. Get to know the character of the environment, geographical structure and culture of the people. So that in sustainable development / architecture, it is important to be categorized according to the culture of different ethnic groups and nations. The concept of architecture here, according to the message in the Qur'an cannot be universalized.

\subsection{Correlation Between the concept of sustainability in Islam and sustainable architecture}

In accordance with the explanation above, the following table describes the correlation between the concept of sustainability in Islam and sustainable architecture; 
Table 1. Correlation Between the concept of sustainability in Islam and sustainable architecture

\begin{tabular}{|c|c|}
\hline $\begin{array}{c}\text { The Revelation (Firman) Allah in Sustainability } \\
\text { Architecture }\end{array}$ & Logic \\
\hline $\begin{array}{l}\text { QS An Naziaat } 30 \\
\text { QS Al Anbiyaa } 33\end{array}$ & Energy Saving \\
\hline $\begin{array}{l}\text { QS Al An'am } 96 \\
\text { QS An Naziaat } 31 \\
\end{array}$ & Water Efficiency \\
\hline $\begin{array}{l}\text { QS Al-Araf 31 } \\
\text { QS Al Baqarah } 222\end{array}$ & Reducing CO2 emissions/ Waste \\
\hline $\begin{array}{l}\text { The Prophet -Shallahu Alaihi Wasallam-, he said, } \\
\text { "There is no Muslim who plants trees or plants, then } \\
\text { birds eat it or humans or animals, except he will get } \\
\text { alms because of it". [HR. Al-Bukhoriy in the Book AL- } \\
\text { Muzaro'ah (2320), and Muslims in the Book of Al- } \\
\text { Musaqoh (3950)] } \\
\text { QS Ar Ra'd: 35 } \\
\text { In the Buchary Muslim Hadith, the home of the } \\
\text { Prophet Muhammad is a rectangular building on a } \\
\text { stretch of desert that is arid. }\end{array}$ & $\begin{array}{l}\text { Efficiency of Material Source/ } \\
\text { Site }\end{array}$ \\
\hline QS Al Hujarat: 13. & $\begin{array}{l}\text { Environmentally } \\
\text { Community }\end{array}$ \\
\hline
\end{tabular}

\section{Aplication (Shape / Form) Sustainability Islamic Architecture in Design \\ 4.1. Beleq Gumantar village in North Lombok}

Gumantar is a village that survived the earthquake of 2018 ago in Lombok. The magnitude 7 earthquake struck Lombok since July 2018 and was repeated dozens of times until the end of 2019. About 437 people were killed and injured 1,353 people. The highest number of wounded victims in North Lombok is 640 people. North Lombok Regency is the area that bears the most severe consequences, because it is close to the epicenter.

Most permanent buildings were destroyed, razed to the ground. However, all Beleq villagers who retain local wisdom, their ancestral heritage have survived, clusters of traditional housing remain intact, food is still available

Because of the ability of the building and its environment have survived more than once, we hypothesize that the Village of Beleq Gumantar uses the principles of Islamic Architecture.
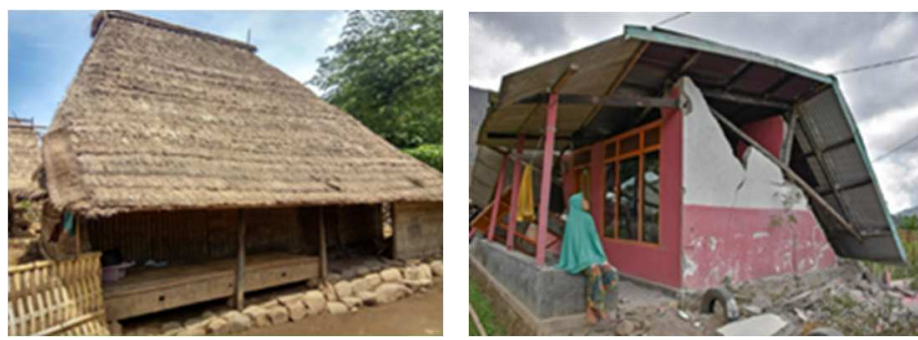
Figure 3. Beleq traditional buildings VS Modern Buildings

Gumantar is one of the eight villages in the Kayangan District of North Lombok Regency. Until now, this village has left several historical sites filled with nuances of customs, especially those based in the village of Beleq Village.

Socio-culturally, the indigenous people of Beleq Village are closely related to the teachings of Islam. This can be seen from the existing cultural sites, continue to live and develop in line with the rhythm of the lives of local people.

The center of the religious aspect is in Gumantar, where the ancient mosque has been built by the saints and scholars' preachers of Islam, while the center of the government at that time was in the village of Beleq Village.

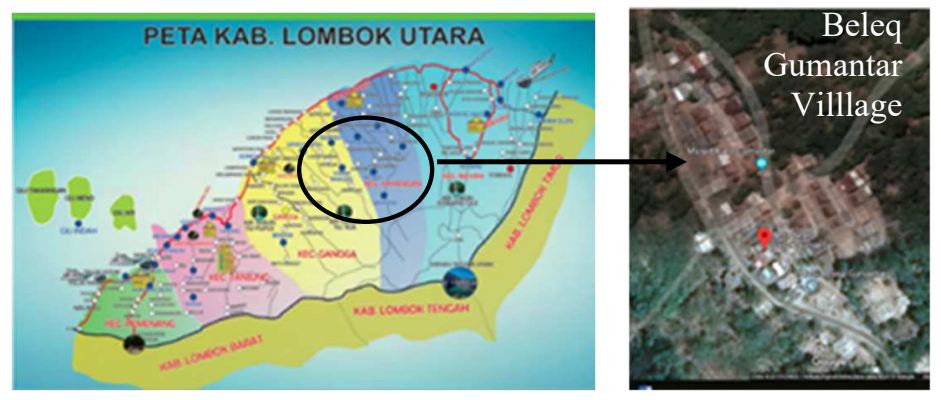

Figure 4. Map Beleq Gumantar Village

Historical sites from Islamic propagators found in Beleq Hamlet, Gumantar Village, Kayangan District, North Lombok Regency, in addition to the mosque, among others, 'Bale Bangar Gubuq', which the local community called Pagalan. This bale, located in the middle of Gubuq Dasan Beleq, with a size of $5 \times 5 \mathrm{~m}$.

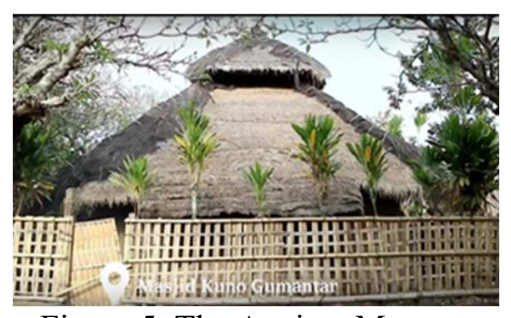

Figure 5. The Ancient Mosque

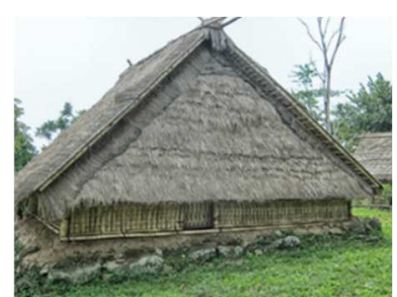

Figure 6. Bale Bangar Gubug

The villagers are very strong in holding customary habits and do not dare to break them. That is what causes spatial planning and buildings that last for hundreds of years.

\subsection{The Concept Of Sustainable Islamic Architecture In The Village Of Beleq Gumantar}

\section{a. Energy Savings}

The orientation of the housing layout in Beleq Gumantar village is North - South, the largest openings (doors and windows) facing the direction of the wind. The walls and roof are 
made of local material, woven bamboo, which produces pores that can put sunlight into the house during the day.
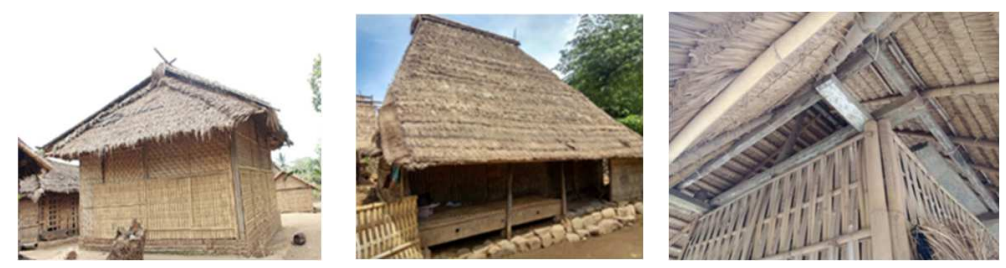

Figure 7. Costum House

Clean water in this village can be drunk without cooking, water is directly flowed through pipes from the south of the village, so it does not need energy for clean water. Do not worry that the water suddenly stops because there is no electricity to flow the water, because the water source is in the highlands.

\section{b. Water efficiency and management system}

North of the Beleq village settlement area is a forest and a traditional grave called the Pendem Forest. In the forest of pendem there is a waterfall called Tiu Pupus. In this forest it is forbidden to cut trees, the law for those who cut trees is to replant a tree or pay with one cow to the adat leader.
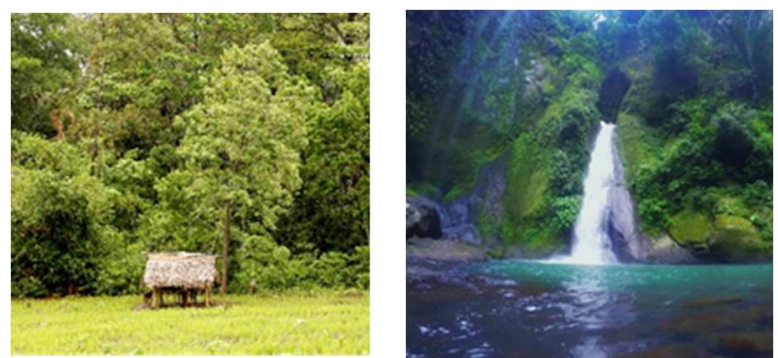

Figure 8. Pendem Forest and Tiu Pupus Water Fall

In the south there is a water source area that should not be built any building, as a source of village irrigation. So that this village has an abundant supply of clean water because it has maintained its rotation system. Water can be drunk directly without cooking.

\section{c. Reducting CO2 Emulcion}

Maintaining the preservation of customary forests by prohibiting cutting trees, is one way to reduce $\mathrm{CO} 2$ gas in the air.

Cow dung waste is used not only as a foundation mixture, but also as a floor coating and cleaner, because it can make the floor shiny. 


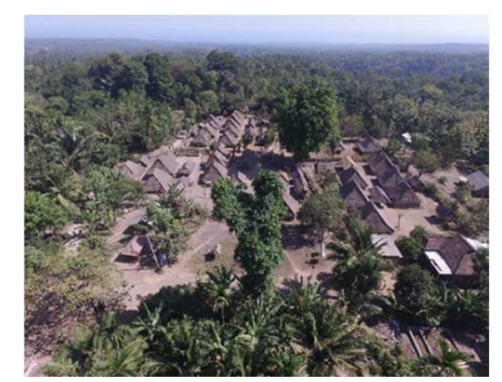

Figure 9 Customary forest around the village

\section{d. Efficiency of Material Sources}

The housing development system in the gumantar village is very much in accordance with adat rules. The structure and construction system used really fully uses environmental resources.

Optimal use of natural materials, by using all the potential of the forest and guarding it by not over-cutting. The punishment for braiding a tree without clarity and is excessive is 1 goat to be eaten in one village, donated 1 quintal of rice and greening in another place.

\section{e. Community}

Around the 16th century AD, when the religion of Islam had begun to spread to all corners of the country, not to mention the spreaders of Islamic teachings to the northern slopes of Mount Rinjani, including in Dasan Beleq Gumantar, so that the Dasan Beleq Gumantar customary community is currently closely related to Islam.

Customary law for environmental and building management has been maintained until now.

\section{Conclution}

Basically the principles of sustainable architecture and green buildings produced by Brundtland commision 1987, have been written in the Qur'an. The principles of green building are in line with the Islamic concept that encourages people to protect the earth from damage by, ordering energy saving, regulating water use, using materials optimally and the commitment of the community to always follow the words of Allah.

The principles of applying Islamic Architecture are . 1. Revelation (Firman Allah), 2. Process the revelation with logic , 3. form / shape

Building area in the village of Beleq Gumantar which has survived hundreds of years and from the earthquake. It can be concluded that the village of Beleq Gumantar is an area that uses sustainable architectural concepts in accordance with Islam. Follow the commands of Allah, apply them with reason, and keep all the commands.

\section{References}

[1] Putri Suryandari, "Mix and Match Traditional and modern technology, toward Sustainable Architecture Housing in the Tropics," in 6th Euroseas Conference, 2007, p. 210. 
[2] P. Suryandari, "Menggali Konsep Arsitektur Cerdas Berbudi Luhur Sebagai Basik Pendidikan di Arsitektur Budi Luhur," Buku wisuda magister, sarjana dan ahli madya univ Budi Luhur 2014, DKI Jakarta, p. 90, 2014.

[3] A. Fikriarini, "ARSITEKTUR ISLAM: Seni Ruang dalam Peradaban Islam," El-HARAKAH (TERAKREDITASI), vol. 12, no. 3, pp. 194-206, 2011.

[4] Tito, "Rumah Tradisional Nusantara Lebih Tahan Gempa," Media Online, 2018. [Online]. Available: https://tirto.id/rumah-tradisional-nusantara-lebih-tahan-gempa-cQPU.

[5] M. BK, "Makna Tanda Kiamat 'Orang Tak Beralas Kaki Berlomba Tinggikan Bangunan," Bersama dakwah.net, 2015. [Online]. Available: https://bersamadakwah.net/makna-tandakiamat-orang-tak-beralas-kaki-berlomba-tinggikan-bangunan/.

[6] Brundland Commision, "Sustainable Architechture," 1987.

[7] F. L. Z. De Moraes et al., "2 , 2 , 1 ," vol. 5, pp. 223-226, 2018.

[8] I. Thonthowi, S. Wahyuni, and L. Nulhakim, "Penerapan Konsep Islam Pada Perancangan Masjid Salman ITB Bandung,” vol. 01, no. 2, pp. 1-11, 2013. 


\section{UUNICHECK}

$\begin{array}{ll}\begin{array}{l}\text { Submission author: } \\ \text { hldden by privacy settings }\end{array} & \text { Check ID: } \\ 15823747\end{array}$

File name: ICIIS_2019_80

File ID: 20122021 Page count: 13 Word count: 4392 Character count: 27356 File size: 1.25 MB

\section{$1.84 \%$ Matches}

Highest match: 0.91\% with source https:/tuww.huffingtonpost.co/wey-business-school/sustoinable-business_b_567t:31.html

$1.84 \%$ Internet Matches 24

Page 15

No Library Sources Found

\section{$13.6 \%$ Quotes}

Quotes 15

Poge 16

Exclude references is off

$0 \%$ Exclusions

No exclusions found

Replacement

No replaced characters found 